\title{
$\underline{\text { Religion and the English Parish }}$
}

\section{J.F. Merritt}

The historiography of the early modern English parish has pursued curiously divergent paths in recent decades. Some studies have considered parishes chiefly in religious terms, and have tended to see them as embodying cohesive, conservative and inclusive values. Others, by contrast, have studied them principally in social terms, and have presented a starkly different picture of socially divided communities, defined in terms of social differentiation and the emergence of a ruling oligarchy monopolizing local power. ${ }^{1}$ Each approach has tended to regard the other as reductionist in its assumptions, and as a result two incompatible images of the early modern parish have emerged from scholarship that runs parallel but seldom intersects, often drawing upon different types of sources. To study the religious experience of the early modern parish effectively, though, it is vital to take an approach that considers the interaction of the social and the religious more fully, with an eye to the specific political context, and informed by factors that could also be cultural or administrative. This is especially necessary in the context of this volume, as 'parish religion' has tended to assume a very special role in the development of 'Anglicanism'. It is often portrayed as conveying and encapsulating a conservative and inclusive type of Protestantism inculcated by the overriding influence of the Prayer Book. But views of the parish as a heartland of unproblematic

${ }^{1}$ E.g. C.W. Marsh, “ "Common Prayer” in England 1560-1640: the View from the Pew', Past \& Present, 171 (2001), pp. 66-94; K. Wrightson, 'The Politics of the Parish in Early Modern England' in P. Griffiths, A. Fox, and S. Hindle, eds., The Experience of Authority in Early Modern England (Basingstoke, 1996), pp. 10-46. 
'Anglican' values carry presuppositions not only about the ideological impact of the Prayer Book on local men and women but also tacit assumptions about the underlying homogeneity of the English parish and its cohesive character. The multi-faceted reality of English parishes in this period, though, means that religious historians must not discount the significance of wide differences in the social, geographical and political make-up of individual parishes, and the complex ways in which religion interacted with them.

This chapter does not seek to provide a simple description or evocation of church services nor even primarily a discussion of the sociability surrounding church-going. Instead it aims to analyze the factors that made the religious experience of parishioners distinctive in this period, particularly in relation to the impact of national religious policy. The study of the parish takes us to the heart of the early modern Church of England and people's daily religious experiences, and reveals not a stable continuum of conservative values, but a dynamic, richly diverse, and multi-faceted parochial experience.

\section{The early modern parish community}

Our discussion of religion within the parish must begin, however, by recognizing the parish's secular role as a unit of government within post-Reformation society, with a number of vital administrative and social duties to perform. Even if the parish church was no longer the focus of the extensive and elaborate communal ceremonies that characterized the pre-Reformation church, the parish itself had an ever more central role as the lynchpin of Elizabethan religious and social policy. The Tudor state imposed increasing duties on the parish. For example the parish (and its officers) were often named explicitly in parliamentary statutes as those responsible for implementing legislation, and their responsibilities included local poor relief 
and the punishment of vagrants, the levying of local rates, and providing arms for the militia and support for maimed soldiers. ${ }^{2}$

In matters concerning the church and religion, the parish was the level at which the state implemented its legal requirement for all inhabitants to attend church (which they did, beneath the prominently displayed royal arms where prayers were offered for the reigning monarch). Church attendance was thus a mark of political loyalty and obedience. This meant that the religious function of the parish was necessarily inclusive, although it was attendance rather than belief that was monitored. Here, despite some ambiguous evidence and regional variation, an improving picture of attendance seems to emerge from the $1590 \mathrm{~s}^{3}$ The presupposition of universal church attendance had an impact in various ways. The fact that the whole community theoretically gathered in the parish church meant that church services also offered an opportunity for the state to interact directly and regularly with its subjects. These were the occasions when royal declarations and state prayers were read out, official news announced, plague regulations disseminated, and the community exhorted to give thanks for Protestant military victories and royal births, to fast for God's protection against the plague, dearth or Catholic plots, and to contribute to collections ranging from the relief of English prisoners abroad to the rebuilding of St Paul's. ${ }^{4}$

${ }^{2}$ B. Kümin, The Shaping of a Community (Aldershot, 1996), chs. 2-3; E.J. Carlson, 'The Origins, Function and Status of Churchwardens', in M. Spufford, ed., The World of Rural Dissenters 1520-1725 (Cambridge, 1995), pp. 164-207.

${ }^{3}$ M. Ingram, Church Courts, Sex and Marriage in England, 1570-1640 (Cambridge, 1987), pp. 107-8; F. Heal, Reformation in Britain and Ireland (Oxford, 2003), p. 466.

${ }^{4}$ N. Mears, A. Raffe, S. Taylor, and P. Williamson, eds., National Prayers. Special Worship since the Reformation vol. 1 (Woodbridge, 2013); J. Peacey, Print and Politics in the English Revolution (Cambridge, 2013), pp. 77-8. 
The parish also regulated a wide range of the social as well as the religious behaviour of its inhabitants, reporting anti-social or immoral behaviour to the church courts. The monitoring of church attendance was entrusted to the locally-selected churchwardens, but wardens were not just to report to their archdeacon on matters such as parishioners being absent from communion or behaving in a disorderly fashion in the church, but also about the conduct of church officials including the minister himself, and on the state of the church fabric. $^{5}$

The parish may thus have been a unit of administration, answering to two chains of command -- one secular and one ecclesiastical -- but it was obviously much more than that. The early modern parish also inherited a whole body of broader assumptions about the social role that the church would perform in promoting Christian fellowship, social harmony and order. In the medieval period such ideas were reinforced in myriad forms of ritual and festive activity that brought the community together. While many of these potentially unifying activities disappeared at the Reformation because of their 'superstitious' associations, some remained, and the model of the parish church as the spiritual heart of the community, promoting cohesion, and as the forum for socially ameliorative activities, was still deeply ingrained.

This can be observed in the sacrament of communion. This was one of only two sacraments to be retained within the Church of England (along with baptism), and participation was a requirement overseen by the churchwardens and minister. The significance attached to the ceremony blended deeply spiritual elements with important social ones, despite changes to its theological underpinnings within the English Church. The ceremony assumed that all eligible inhabitants were physically present, as well as symbolically united, in a 'feast of charity', and, significantly, charitable collections in church

\footnotetext{
${ }^{5}$ J. Spurr, The Post-Reformation 1603-1714 (Harlow, 2006), pp. 240-1.
} 
tended to peak at Easter communions. Parishioners were theoretically required to take communion three times a year, but in practice it was often taken only once, at Easter. Before taking the sacrament, the Prayer Book stipulated that parishioners should be 'in charity' with their neighbours, a proviso that many took very seriously and there is also plentiful evidence that ministers were prepared to bar from communion those who were in dispute with their neighbours, or any who were 'an open and notorious evil liver, so that the Congregation by him is offended' (as the Prayer Book put it). Although attendance levels at communion might vary, this does not seem to have reflected indifference to the sacrament. It is also clear that to be excluded from communion (less common after 1604) could be a deeply distressing experience, with both spiritual and social ramifications. ${ }^{6}$ Communal norms could thus be strengthened by acts of temporary exclusion, and there were other rituals of exclusion too, in the public shaming and loss of 'credit' of those convicted of drunkenness or Sabbathbreaking, who might be required to admit their fault publicly in church after morning prayer on Sunday, while those convicted of sexual misdemeanours performed public penance in church with a white sheet. ${ }^{7}$

As we have noted, collective ritual activities were undoubtedly attenuated compared with the pre-Reformation parish: the extraordinary medieval round of feast-days and

\footnotetext{
${ }^{6}$ A. Hunt, 'The Lord's Supper in Early Modern England', Past \& Present, 161 (1998), pp. 41 51; J.F. Merritt, The Social World of Early Modern Westminster: Abbey, Court and
}

Community 1525-1640 (Manchester, 2005), p. 292; C. Haigh, 'Communion and Community: Exclusion from Communion in Post-Reformation England', JEH, 51 (2000), pp. 722, 724, $738-40$.

${ }^{7}$ Ingram, Church Courts, pp. 53-4; 336-7. Eg. London Metropolitan Archives (hereafter LMA), DL/C/617, n.f. (March 1604/5, May 1605); DL/C/306, fos. 55b, 383; Westminster Archives Centre, E19, fo. 46v. 
processions were severely curtailed as part of general restrictions on saints' days and the removal of elements of superstition. Nevertheless, among those rites that did survive, those associated with the life-cycle -- such as baptism, churching, marriage and funerals -- were important public, sociable activities as well as marking the entry and departure of parishioners from the Christian community. ${ }^{8}$ Even in times of plague, church and secular authorities struggled to prevent families and neighbours from organizing and attending public funerals, events that often included doles to the parish poor. ${ }^{9}$ When parishioners were sick, prayers could be solicited from the community assembled in church. In 1630s London it was reported that petitions for prayers for named individuals were printed as 'bills' and handed to the minister to read out. ${ }^{10}$ Other rituals and festivities punctuated the calendar year, such as the Rogationtide perambulation of the parish, which not only confirmed parish boundaries for legal and financial purposes, but also encompassed processions involving young and old, the distribution of charity, and festive eating and drinking. ${ }^{11}$ The festive aspects of Christmas

${ }^{8}$ D. Cressy, Birth, Marriage and Death (Oxford, 1997); C. Gittings, Death, Burial and the Individual in Early Modern England (1984); R. Houlbrooke, Death, Religion and the Family in England 1480-1750 (Oxford, 1998); P. Marshall, Beliefs and the Dead in Reformation England (Oxford, 2002), ch. 4.

${ }^{9}$ Robert Hill, The Pathway to Prayer and Piety (1613), pp. 146-7; P. Slack, The Impact of Plague in Tudor and Stuart England (1985), pp. 210, 234, 296-8.

${ }^{10}$ Peter Heylyn, 'A Brief Discourse Touching the Form of Prayer Used Before Communion' in Ecclesia Vindicata (1657), pp. 340-41; Thomas Edwards, Gangraena (1646), pt.3, sig. [Ii4r].

${ }^{11}$ R. Hutton, The Rise and Fall of Merry England: the Ritual Year 1400-1700 (Oxford, 1994), pp. 34-6, 142-3, 175-6; F. Heal, Hospitality in Early Modern England (Oxford, 1990), 
Day itself, of course, were just one of the many reasons that it attracted the ire of puritans in the $1650 \mathrm{~s}^{12}$ In addition to these traditional holidays, this period also saw the emergence of a 'Protestant calendar', with bells, bonfires and feasting accompanying days that commemorated significant dates for the Protestant Church and state, such as the monarch's birthday and the commemoration of the foiling of the Gunpowder Plot. Needless to say, these events were also routinely associated with special sermons and prayers. ${ }^{13}$

Other local feasts and customs survived more patchily, and were often discontinued due to fears of 'popery' or disorder. ${ }^{14}$ Among the more notable of these were parish feasts to celebrate the anniversary of the dedication of the church, and so-called 'church ales', where ale was brewed and sold (principally to meet the costs of church repair and other parish expenses). It was reported of Somerset in the 1630s that these feasts were not only popular there, but also that they promoted charitable giving to the poor, hospitality from the rich, and 'the increase of love and unity', such that 'many suites in law have bin taken up at these feasts by mediation of friends, which could not have bene soe soone ended in Westminster Hall'. More generally, the repair, rebuilding and decoration of the parish church could often involve many inhabitants working collectively, with the parish here acting as a focus of charity, identity, and cultural endeavour. ${ }^{15}$

ch. 9; Merritt, Social World, pp. 208-12; A. Walsham, The Reformation of the Landscape (Oxford, 2011), pp. 252-62, 267.

${ }^{12}$ R. Hutton, The Stations of the Sun (Oxford, 1996), chs. 1-6.

${ }^{13}$ D. Cressy, Bonfires and Bells (1989), pp. 50-7; Hutton, ise, pp. 146-51, 186-7.

${ }^{14}$ E.g. P. Collinson, 'The Shearman's Tree and the Preacher' in P. Collinson and J. Craig, eds., The Reformation in English Towns 1500-1640 (Basingstoke, 1998), pp. 205-20.

15 TNA, SP 16/250, fo. 56r-v; J.F. Merritt, 'Puritans, Laudians, and the Phenomenon of Church-building in Jacobean London', Historical Journal, 41 (1998), pp. 940-50. 
The parish also maintained its communal identity by manufacturing and sustaining a sense of continuity, and by fostering collective memory (albeit locked in a complex dialogue with its pre-Reformation past). The focus of memorialization in the medieval Church had been particularly linked to prayer and masses for the dead. In the post-Reformation period these patterns of memorialization changed but were still prominent, evidenced in the commemoration of parish benefactors in funerary monuments, painted boards and stained glass, in sermons, and sometimes in elaborate ritual acts of commemoration where bequeathed alms were distributed. Such acts of charity and remembrance were still upheld in roughly de-Catholicized rather than confessionally specific form, while parish customs were supported by a ubiquitous and still powerful rhetoric of things being done 'time out of mind'. ${ }^{16}$ This was underpinned by the parish's continuous legal status and by the fact that parishioners often acted as guardians of things held in common (such as common land or benefactions). Despite the depredations of the Reformation period, the parish still acted as the receptacle for community interests on a local level: thus, after the dissolution of the chantries, endowments that funded 'non-superstitious' purposes such as education or poor relief were protected, while in other cases parishes acted promptly to obtain a communal resource. Thus the parish of St Botolph Aldersgate almost immediately gained possession of the hall of the dissolved Trinity fraternity to serve as a venue for parish meetings. ${ }^{17}$

\footnotetext{
${ }^{16}$ I. Archer, 'The Arts and Acts of Memorialization in Early Modern London' in J.F. Merritt, ed., Imagining Early Modern London (Cambridge, 2001), pp. 89-113; Merritt, Social World, pp. 273-9; Marshall, Beliefs and the Dead, p. 304.

${ }^{17}$ London and Middlesex Chantry Certificate, 1548, ed. C.J. Kitching (London Record
} Society, 16, 1980), pp. x, xxxii; Parish Fraternity Register Fraternity of Holy Trinity and SS Fabian and Sebastian, ed. P. Basing (London Record Society, 18, 1982), p. xxvi. 


\section{$\underline{\text { The parish and religion }}$}

As we can see, the parish could thus in theory perform a whole range of roles in building and sustaining the local community - its identity, customs, values, and memory. But we cannot assume that parochial religious activities were therefore an uncomplicated reflection of these cohesive forms of communal endeavour and ritual activity, not least because the postReformation parish also had an urgent evangelical task to perform. In the century following the Reformation, the Church of England faced the task of building a Protestant nation, of teaching the true Protestant religion and instilling its values in the beliefs and practices of parishioners. This raised a basic question of what religious functions the parish could and should serve, given that the state's concern was focused on church attendance rather than belief. The challenge for Protestant ministers, in particular, was to decide how far the social and administrative functions of the parish might aid or frustrate the attempt to improve the religious lives of the community. Could parochial structures, rituals and traditions facilitate Protestant pastoral, evangelical aspirations, or did they merely serve to impede them? Who controlled the parish's religious life in practice, and how might this affect the role that religion played in the local community?

Before discussing how parochial religious experience was shaped by individuals and institutions, we must note some of the ways in which the ideal of the cohesive parish community gathered together in church was often impossible to realize. One hinderance relates to the size of parishes, since the Reformation did nothing to reshape the geographical pattern of medieval parishes, which sometimes extended over large areas. The role of the parish as the cornerstone of local society, inculcating Protestant ideas and maintaining some form of moral and religious discipline, was also affected by the government's subsequent failure to adjust the number and size of parishes to reflect changes in population. The sixteenth and seventeenth centuries witnessed tremendous demographic expansion as well as 
changes to the distribution of population, in particular the striking growth of the capital and other urban centres. In towns this resulted in parishes where it was impossible to assemble the whole body of parishioners in church at any one time. At the same time, in rural areas (especially in the north) parishes were often too large for their scattered populations, making regulation of conformity more difficult and potentially impeding the regular preaching and catechising that facilitated the word-centred piety of Protestantism. ${ }^{18}$ However, from the 1590s onwards, some parts of northern England gained chapels of ease, while programmes of church refurbishment in urban areas were accompanied by campaigns to enlarge churches, adding galleries and refiguring interiors in order to accommodate larger numbers. Significant amounts of money were spent on these building projects and some churches in the capital were substantially rebuilt. Parishes in the capital also adopted practices such as 'Easter' communions that were staggered over many weeks to ensure fuller participation by inhabitants. ${ }^{19}$ There were episodic attempts to create new parishes in the pre-civil war period, and some subdivisions and amalgamations of parishes in the Interregnum, but the uncertainties of the $1650 \mathrm{~s}$ meant that these anomalies were still unaddressed at the Restoration. In any case, enormous tenacity was needed to set up new parishes, since this required an act of Parliament as well as large sums of money to build a new church and to provide an income for a minister. The case of St Paul Covent Garden (a parish created $\underline{\text { ex }}$ nihilo in the 1630s) perhaps illustrates why the solution of creating new parishes was so

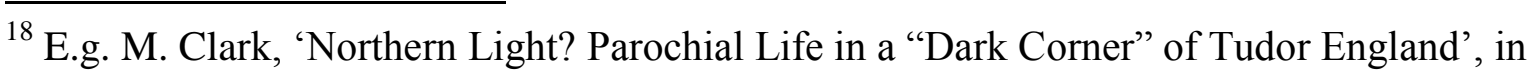
K.L. French, G. Gibbs and B. Kümin, eds., The Parish in English Life 1400-1600 (Manchester, 1997), pp. 66-7.

19 Heal, Reformation, p. 444, Merritt 'Church-building', pp. 935-60; J.P. Boulton, 'The Limits of Formal Religion: the Administration of Holy Communion in Late Elizabethan and Early Stuart London', London Journal 10 (1984), pp. 135-54. 
rarely attempted, with countless complications and acrimonious disputes -- over local rates, ecclesiastical patronage, architectural style, allocation of pews, and control of the vestry -that stretched well into the Restoration period. ${ }^{20}$

The ideal model of the whole community assembled in the parish church was a powerful one, of course, and drew upon familiar discourses of the body politic, but it could also be frustrated in other ways. There was always a certain number of parishioners who did not attend their parish church at any given time. It is more helpful, however, to think of these as more fluid, fluctuating groups rather than as simple 'blocs' of non-attenders. Such behaviour might vary across the individual's position in the life-cycle. Evidence from church court records and indeed much contemporary comment particularly draws attention to the patchier attendance of the young, too easily tempted by the rival attractions of the alehouse or fiddlers, pipers and dancing. Also absent from the church were the small numbers who had been excommunicated, although few people seem to have remained contumacious for long, beyond highly mobile groups, such as servants. ${ }^{21}$ But the group whose relationship with the parish was most truly problematic were Roman Catholics. Scholarship specifically on the English parish has often tended to overlook this group, leaving them to more specialist recusant history. Yet throughout our period, many parishes, especially in parts of the north and Midlands, counted Catholics among their inhabitants. Their presence was potentially

${ }^{20}$ J.F. Merritt, " "Voluntary Bounty and Devotion to the Service of God"? Lay Patronage, Protest and the Creation of the Parish of St Paul Covent Garden, 1629-41', English Historical

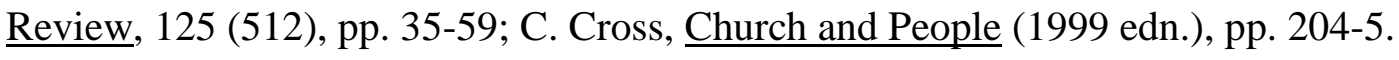
${ }^{21}$ E.g. W. Hale, ed., A Series of Precedents and Proceedings in Criminal Causes (1847), pp. 218, 219, 235, 242; P. Collinson, The Religion of Protestants (Oxford, 1982), pp. 206-7, $224-$ 6; Ingram, Church Courts, p. 365; C. Haigh, The Plain Man's Pathways to Heaven (Oxford), pp. 68-9, 72 . 
ambiguous. Laws against popish recusancy encouraged many Catholics to slip in and out of conformity, with perhaps the head of the household attending the parish church as necessary to avoid prosecution. ${ }^{22}$ This meant that Protestant parishioners, including the godly, could be forced to attend the same services and sermons as their so-called 'church papist' neighbours (Catholics who attended Protestant services only to avoid statutory fines), while known Catholics were sometimes buried in the local churchyard or commemorated by monuments in the parish church. Few Catholics, though, were quite as audacious as Lady Wotton, who was fined $£ 500$ by High Commission in 1633 for placing a 'bold epitaph' on her husband's monument at Boughton Malherbe, stating that he had died a true Catholic of the Roman Church. ${ }^{23}$ Though periodically the prosecution of recusants loosened or tightened (often in response to the international situation), in some regions enforcement was known to be more slack. Some light is shed on forms of co-existence, however, by the Jesuit Henry Garnet's advice to fellow Catholics that it was permissible for them to accompany the bodies of their Protestant neighbours to burial, as long as they held back from the service. However, in other areas of the north (and especially in Lancashire) the high numbers of relatively unmolested

\footnotetext{
${ }^{22}$ A. Walsham, Church Papists (Woodbridge, 1993), p. 95; M. Questier, 'Conformity,
} Catholicism and the Law' in P. Lake and M. Questier, eds., Conformity and Orthodoxy in the English Church, c.1560-1660 (Woodbridge, 2000), pp. 237-61.

${ }^{23}$ P. Marshall, 'Confessionalization and Community in the Burial of English Catholics, c.1570-1700', in N. Lewicky and A. Morton, eds., Getting Along? Religious Identities and Confessional Relations in Early Modern England (Farnham, 2012), p. 62; L.E.C. Evans, 'The Wotton Monuments', Archaelologia Cantiana, 87 (1972), p. 25. 
Catholics more consistently stirred up puritan opposition and resulted in more polarized communities. $^{24}$

Even when most inhabitants did indeed gather in the parish church this did not, of course, guarantee harmony and sometimes it generated precisely the opposite. The very fact that the church was the one place where the entire community gathered inevitably meant that it was also a place for social display and competition, which was reflected in the location of one's seat and place of burial. Seating within the church was also seen as a symbolic representation of a theoretically fixed local hierarchy, delineated by social and economic status as well as by age and gender. But the finer gradations of such hierarchies were often changing or open to dispute, and acrimonious conflicts could lead to confrontations in church (where churchwardens or vestries allocated pews according to custom) and thence into the church courts. ${ }^{25}$ At other times, clergymen might fret that the obligations of social deference were interfering with parishioners' religious duties: the Laudian John Swan urged parishioners not to interrupt their prayers by standing up and acknowledging when their social superiors entered the church, as "there bee other times and other places to shew your dutie and respect to Man'. ${ }^{26}$

Further practical problems could sometime interfere with the religious use of the parish church. The religious message implicitly conveyed by the church interior had been one of the key targets of Protestant reform, resulting in white-washed churches, purged of

${ }^{24}$ A. Walsham, A Charitable Hatred (Manchester, 2006), chs. 3-6; Marshall, ‘Confessionalization and Community’, p. 69.

${ }^{25}$ Merritt, Social World, pp. 214-23; C.W. Marsh, 'Sacred Space in England, 1560-1640: the View from the Pew', JEH, 53 (2002); N. Alldridge, 'Loyalty and Identity in Chester Parishes, 1540-1640' in S. Wright, ed., Parish, Church and People (1988), pp. 94-7.

${ }^{26}$ John Swan, Profano-mastix (1639), pp. 44-5. 
'superstitious' church goods. However the architecture of medieval churches, with their sidechapels and processional routes, still reflected the ceremonial and sacramental character of medieval Catholicism. English churches gradually-and more or less successfullytransformed their interiors from ones designed primarily for ceremonial purposes into spaces for preaching the word of God and the administration of communion in both kinds to parishioners. Nevertheless this was sometimes a protracted process. The location of the communion table, pulpit and reading desk (regardless of later disagreements among Protestants regarding the religious significance of their disposition) and the ways in which the reception of communion was arranged, often required adaptation to the surviving architecture of the church, which could make the experience of worship vary considerably in different communities. Parishioners of St Martin in the Fields were ultimately forced to move pillars in the church in 1596 'that the People may better here [sic] the Preacher. ${ }^{27}$

Faced with both practical problems that could hinder the transition to Protestant worship, and with the religiously ambiguous inheritance of parochial rituals, how was the religious experience of the parish shaped in the post-Reformation period? As we shall see, the parishioners themselves could make a decisive contribution, but a central role was obviously performed by the individual clergyman.

On a basic level, the presence or absence of a resident clergyman was a key variable in English parishes. The poverty of many livings encouraged pluralism, non-residence and

${ }^{27}$ William Harrison, The Description of England, ed. G. Edelen (Washington D.C., 1994), pp. 33-6; Heal, Reformation, pp. 442-3; R. Whiting, The Reformation of the English Parish Church (Cambridge, 2010); St Martin in the Fields: The Accounts of the Churchwardens 1525-1603, ed. J. Kitto (1901), p. 484. 
the employment of poorly-qualified curates, which inevitably limited contact between laity and their vicar, and inhibited access to the regular services and preaching needed to promote Protestantism. Complaints over non-residency and 'dumb dog' ministers prompted the many puritan surveys of the clergy in the Elizabethan period, although standards seem to have improved significantly by the reign of James. ${ }^{28}$ Nevertheless, delicate and socially awkward matters of finance and dependency could loom large over the minister's relationship with his parish and also affected his potential impact in religious affairs. For example, how tithes were paid, and how insistent the clergyman was in collecting them, even in times of dearth, often exacerbated tensions between the minister and his flock regardless of other religious disagreements. ${ }^{29}$ The Laudian Brian Walton's ceremonialism might in itself have alienated his congregation at St Martin Orgar in the 1630s, but his behaviour on arrival in the parish would not have helped to win them over. This included seizing the profits from a recent successful but long-standing parish lawsuit and then claiming sole credit for it, which he commemorated with an inscription in the church. ${ }^{30}$ Equally, disagreements over church fees for baptisms, marriages and burials were significant flashpoints. This income could be vital to the clergy, but could encourage unscrupulous conduct. The royal Commission on Fees in the 1620s and 1630s uncovered a number of examples of ministers destroying old tables of fees in order to raise charges. The curate of St Giles in the Fields went even further: he was

\footnotetext{
${ }^{28}$ Heal, Reformation, pp. 405-8; Ingram, Church Courts, pp. 86-7.

${ }^{29}$ C. Hill, Economic Problems of the Church (Oxford, 1956), pp. 157-8.

${ }^{30}$ LMA, P69/MTN2/B/001/MS0959/001, fos. 119r, 133r, 144v, 149v, 164v, 165r, 167r, 177v, 181r, 188v; TNA, SP16/302/49; The Articles and Charge proved in Parliament against Doctor Walton, Minister of St. Martins Orgars in Cannon Street (1641).
} 
accused of refusing to bury one parishioner who had opposed him in parochial affairs, and declining to conduct a pauper burial until he had been paid in advance. ${ }^{31}$

When a minister was resident, his own religious attitudes - especially if he was a puritan --could obviously have a profound impact on the character of public worship in the parish (a point to which we shall return). Although it is important not to pit an exclusively 'sermon-centred' piety against a 'sacrament-centred' piety in this period, the relative emphasis that ministers placed upon the word and sacraments undoubtedly varied, and contemporaries were certainly capable of placing them in hostile juxtaposition. ${ }^{32} \mathrm{~A}$ minister of puritan instincts might also bring a distinctive approach to his pastoral duties. The puritan George Gifford's fictional dialogue between 'Atheos' and 'Zelotes' memorably invoked the distinction between a minister who mixed easily with his parishioners, above all promoting good fellowship and reconciling neighbours over a game of cards or a drink, as opposed to the godly minister who specifically avoids such activities and concentrates instead on spending time in his study preparing his sermon. At the heart of the ministry extolled by the puritan minister Zelotes was the division between the godly and ungodly, based on particular readings of the doctrine of grace and predestination. Zelotes accepts the complaint that the true minister brings division into the local community ("whereas before they loved together, now there is dissention sowne among them') by denying the ultimate primacy of peaceful coexistence and good fellowship: 'Woulde yee have God and the Divell agree together?

${ }^{31}$ TNA, E215/58F, pp. 114-5, 122; E215/1232/1 and 1232/2; Hill, Economic Problems, pp. $182-6$.

${ }^{32}$ A. Hunt, The Art of Hearing (Cambridge, 2010), pp. 52-4; J. Maltby, Prayer Book and People in Elizabethan and Early Stuart England (Cambridge, 1998), pp. 67-8 
woulde ye have the godlie and the wicked for to bee at one? ${ }^{33}$ The model of godly minister presented by Gifford was certainly familiar to contemporaries. We can find ministers such as Stephen Dennison in London and Richard Bernard in Batcombe, Somerset, introducing publicly divisive elements into parishes by denouncing specific local sinners from the pulpit, a practice known as 'particularizing'. ${ }^{34}$ The popular nonconformist minister Samuel Hieron was among those who sowed division in his Devon parish still further by using the occasion of funeral sermons to condemn the sins of the deceased, although the practice was defended in print by puritan authors as a means of instruction to the living. ${ }^{35}$

This being said, while the picture emerging from printed literature of the period (including Gifford's dialogue) tends to suggest a sharp contrast between puritan ministers and those wedded to a more traditional role promoting social cohesion, the reality appears to have been more complex. ${ }^{36}$ Firstly, the extent to which godly men and women truly held themselves aloof from their neighbours in practice has rightly been queried. When around 1630 the redoubtable John White of Dorchester devised a covenant for his congregation as a condition of their receiving communion, he did not include a provision to avoid the company

${ }^{33}$ George Gifford, A Briefe Discourse of Certaine Points of the Religion which is Among the Common Sort of Christians, Which may bee Termed the Countrie Divinitie (1582), sigs. A1A3, 46v.

${ }^{34}$ P. Lake, The Boxmaker's Revenge (Manchester, 2001), pp. 65, 311-14; Haigh, Plain Man's Pathways, pp. 21-4.

${ }^{35}$ Samuel Hieron, The Worldling's Downfall (1618), To the Christian Reader (preface); Emmanuel Utie, Matthew the Publican. A Funeral Sermon, preached in St Stephen Walbrook the 11 of March 1615 (1616), To the Christian Reader (preface).

${ }^{36}$ Eg. Ingram, Church Courts, pp. 118-23. 
of the ungodly. ${ }^{37}$ In addition, puritan ministers were not necessarily averse to fulfilling the traditional social role of promoting reconciliation among their parishioners, as the notable efforts of the famously godly but pastorally sensitive puritan minister Richard Greenham testify. ${ }^{38}$ The informal role of ministers across the religious spectrum in reconciling members of their flocks and arbitrating in lawsuits is also frequently alluded to in church court records. Reconciliation could, of course, form part of a larger puritan agenda in preparing the godly to receive communion: one notable puritan pastor provided his congregation with a list of no fewer than eight questions through which individuals could test themselves to ensure that 'you are so reconciled, that you love your brother'. ${ }^{39}$ But here the different social and religious imperatives for reconciliation were likely to have been mutually supportive.

Some historians have argued that puritan-inflected Protestantism purveyed an unpalatable and divisive message that was also virtually impossible for ministers to convey to their flocks. ${ }^{40}$ But the career of Robert Hill, which largely unfolded in Jacobean London, suggests otherwise. There can be no question that Hill's message from the pulpit was a rigorously Calvinist one. In the 1590s, this disciple of William Perkins specifically attacked John Overall (later dean of St Paul's) for having suggested that predestinarian doctrine should be modified to make it more palatable for a lay congregation. Yet Hill was also famous for his pedagogical gifts: he excelled in the popularization of puritan doctrines via homely

\footnotetext{
${ }^{37}$ Collinson, Religion of Protestants, pp. 272-3.

${ }^{38}$ Samuel Clarke, The Lives of Two and Twenty English Divines (1660), p. 15; E. Carlson and K.L. Parker, 'Practical Divinity': the Works and Life of Revd Richard Greenham (Aldershot, 1998), pp. 81-3.

${ }^{39}$ Ingram, Church Courts, p. 111; Hill, Pathway, ii. p. 27.

${ }^{40}$ C. Haigh, 'The Taming of Reformation: Preachers, Pastors and Parishioners in Elizabethan and Early Stuart England', History 85 (2000), pp. 572-88.
} 
images and simple catechetical formats. Hill's message was clear but also subtly nuanced. If his predestinarian doctrine was unequivocally polarized, he nevertheless presented election as a universal aspiration, and talk of 'brethren' and 'community' was woven into his discourse in ways that could speak to a godly elite but also to the broader parish population. Hill essentially offered a vision of the community that recognized the godly and their special duties without severing them from their neighbours. ${ }^{41}$ The stark binary division between the godly and the ungodly invoked by Gifford and others may have been rhetorically appealing, but it is not only Hill's example that suggests that puritan ministers could in practice adopt a more nuanced and complex approach to their role as pastor. Describing his parochial congregation in the 1650s, Richard Baxter (albeit in the context of restricted communions) divided his flock into no fewer than twelve different groups, and was optimistic that even some of those who 'seem to be ignorant of the very Essentials of Christianity' were yet 'tractable and of willing minds'. 42

An effective ministry was also crucially dependent on the clergyman securing the effective support of at least a portion of his flock, although this was complicated by the fact that the views of parishioners were generally not taken into consideration in clerical appointments. After the Reformation, many advowsons (the right of presentation to a living) previously exercised by religious houses passed to the Crown. In Essex, for example, nearly half the advowsons in the county passed to the Crown at the dissolution, although about half of these were granted away within a few years. This large-scale acquisition of advowsons by

${ }^{41}$ J.F. Merritt, 'The Pastoral Tightrope: a Puritan Pedagogue in Jacobean London' in T.

Cogswell, R. Cust and P. Lake, eds., Politics, Religion and Popularity in Early Stuart Britain (Cambridge, 2002), pp. 143-61.

${ }^{42}$ Richard Baxter, Confirmation and Restoration, The Necessary Means of Reformation and Reconciliation (1658), pp. 157-65. 
laymen was an important feature of the Reformation, with the patronage rights acquired by many gentry along with the purchase of manors. ${ }^{43}$ Advowsons thus provided opportunities to advance clergy of a particular religious complexion, a strategy famously pursed by the puritan Feoffees for Impropriations under Charles I, and reflected in the great puritan patronage networks that depended on noble and gentry families in East Anglia and the Midlands, where individual noblemen might control a formidable number of advowsons. In Elizabethan West Suffolk, for example, the radical puritan Sir Robert Jermyn controlled ten livings and Sir John Higham, another four, while puritan gentry and noblemen including Lord North and Sir Nicholas Bacon presented to at least 30 more Suffolk parishes. ${ }^{44}$ But lay patronage was not always used for godly ends. In some cases, lay patrons neglected the needs of parishioners and simply left livings unfilled, as was the case in several parishes in Colchester at the end of Elizabeth's reign, or imposed crippling bonds on prospective ministers to maximize their financial advantage ${ }^{45}$ Other factors that might dictate the choice of ministers included family ties, an institutional link, or mere simony, while many livings remained in the hands of the Crown and bishops. Others, though, were controlled by organizations such as colleges and corporations, and the latter often tended to be puritan or anti-Laudian in their sympathies, although in these cases advowsons were less common than the sponsoring of a lectureship. ${ }^{46}$ In Ipswich, though, there was a long pre-Reformation tradition of parochial nomination of clergy, and after the Reformation five livings came

${ }^{43}$ J. E. Oxley, The Reformation in Essex to the Death of Mary (Manchester, 1965), pp. 263 -

4; Hill, Economic Problems, pp. 56-7.

${ }^{44}$ P. Collinson, The Elizabethan Puritan Movement (1967), pp. 337-8.

${ }^{45}$ R.D. Smith, The Middling Sort and the Politics of Social Reformation: Colchester 1570-

1640 (New York, 2004), p. 133; Hill, Economic Problems, pp. 63-7.

${ }^{46}$ P. Seaver, The Puritan Lectureships (Stanford, California, 1970), p. 89. 
directly into the hands of parishioners, who proceeded to both nominate and to oust their clergyman. In the capital, at least thirteen parishes controlled their own advowson. ${ }^{47}$

Parishes that held their own right of presentation echoed the general Presbyterian principle that the minister should be chosen by his congregation (albeit that in Reformed churches abroad this was usually on the recommendation of the classis). This was an ideal that was sometimes gestured towards in puritan circles even in cases where the parishioners did not themselves own the advowson. Thus when the godly gentleman Sir Robert Harley who possessed the Herefordshire advowson of Brampton Bryan - appointed a new minister in 1634, it was emphasized that this was with the parishioners' consent (and specifically that the local bishop's permission was irrelevant). ${ }^{48}$ The possibility of parishioners (or indeed lay patrons) acquiring the right to appoint their own minister also troubled William Laud, and when he was presented with schemes for new chapels and churches in the 1620s and 1630s he monitored them closely and sometimes intervened to prevent what he called a "popular nomination' (as in the case of Hammersmith in 1629). ${ }^{49}$

But parishioners did not need to control the patronage of the living in order to exert a significant influence on local religious affairs. The exercise of lay power in parishes by vestries -- bodies typically consisting of 12 or 24 of the principal inhabitants of the parish --

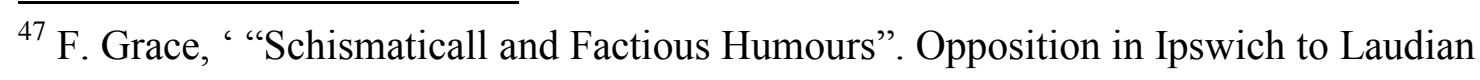
Church Government in the 1630s' in D. Chadd, ed., Religious Dissent in East Anglia (Norwich, 1996), pp. 104-5; Seaver, Puritan Lectureships, p. 138.

${ }^{48}$ Collinson, Elizabethan Puritan Movement, pp. 338-40; J.T. Cliffe, The Puritan Gentry (1984), p. 188.

${ }^{49}$ Merritt, 'Voluntary Bounty', pp. 41-2; J.F. Merritt, 'Contested Legitimacy and the Ambiguous Rise of Vestries in Early Modern London', Historical Journal 54 (2011), pp. 3943; Hill, Economic Problems, pp. 59, 299. 
became more widespread over this period, although they were principally concentrated in towns. Vestries are generally seen as a post-Reformation phenomenon, although there is little doubt that medieval parishes depended on their 'chief parishioners' to carry out many duties. The term 'vestry' was used as early as 1507 in the London parish of St Christopher le Stocks, and the use of the term by Bishop Grindal in 1567 in a circular letter to the London clergy demonstrates that its meaning was already assumed to be familiar. Vestries gained a higher profile as they undertook the wider range of tasks increasingly allocated to parishes by parliamentary statute in the sixteenth century. As such tasks grew in volume and complexity, so quotidian parish government increasingly became the preserve of a more narrow body of administrators, and a distinction becomes apparent between a small body of inhabitants meeting more regularly for day-to-day administration, and larger meetings of the whole parish to elect parish officers every Easter. ${ }^{50}$ It is too simplistic to see this merely as a matter of oligarchical usurpation: the image of the vestry as the paternalistic embodiment of the parish and custodian of its legal and financial interests was crucial both to the vestry's selfidentity and to local acceptance of its authority as a bulwark of parochial order and unity. The formal creation of a vestry in All Hallows Staining in 1574 specifically noted how the lack of good orders and government were the cause of 'varience strife and enemitie ... Betweene parishioners neighbours and Frendes'. ${ }^{51}$ While they constituted a decision-making body whose members formed a self-selecting elite, vestries were nevertheless meant to reflect local opinion more broadly. Yet the vestry's executive oversight of the parish meant that it

\footnotetext{
${ }^{50}$ Lambeth Palace Library, CM VII/69; S. and B. Webb, English local government (The parish and the county) (1906, rprt 1924), pp. 38-9n, 178, 183; S. Hindle, 'The Political
} Culture of the Middling Sort in English Rural Communities, c.1550-1700' in T. Harris, ed., The Politics of the Excluded c.1500-1850 (Basingstoke, 2001), p. 127.

${ }^{51}$ LMA, P69/ALH6/B/001/MS04957/001 (unfoliated). 
regularly took crucial decisions on issues surrounding parish worship, such as changes to the church fabric, furniture and decoration, as well as acting with churchwardens in their response to directives and inquiries from episcopal authorities.

Crucial to the religious experience of the parish was therefore the nature of the relationship between the vestry and the local clergyman (who did not always attend vestry meetings), and this could be problematic. The extent of vestry powers, and the ecclesiastical authorities' concern to protect the rights and authority of the minister, is suggested in the set of limitations contained in new vestry faculties granted by the bishop of London from 1612 onwards. Among other things, these forbade vestries from summoning before them any clergyman, or from 'intermeddling' with the churchwardens' bill of presentment. ${ }^{52}$ Nevertheless, it is not difficult to find vestries brokering agreements with their parish minister that demonstrate where effective power lay, and the ease with which they could wrest control of parochial religion. Thus in 1624 , the vestry of St Olave Jewry paid off the debts of their minister, Thomas Tuke, on condition that 'the divinity lecture shall henceforth be freely read, without his interruption, and also that the choice of the person to read the same lecture shall also forever hereafter rest wholly in the election of the parishioners without molestation or intermeddling herewith' 53

Parish lectureships represented a very effective way in which parishioners could obtain preaching attuned to their religious tastes, especially if these differed from those of their parish minister. Although lectureships had originated as a means of supplementing preaching more generally, they were also frequently seen as a vehicle for promoting puritan preaching and the furtherance of godly programmes of social regulation. ${ }^{54}$ Ideally, of course,

\footnotetext{
${ }^{52}$ Merritt, 'Contested Legitimacy', p. 31.

${ }^{53}$ LMA, P69/OLA2/B/001/MS04415/001, fo. 16r.

${ }^{54}$ Seaver, Puritan Lectureships, chs. 3-4.
} 
minister and lecturer would support each other, and there are certainly cases where this happened perfectly amicably. But the example of Thomas Tuke shows that the lectureship could also be a means of circumventing a minister unsympathetic to the vestry's preferences. The manner in which vestries superintended the creation of parish lectureships was almost calculated to arouse the anxieties of the ecclesiastical authorities. Vestries auditioned candidates to compare their preaching and then voted for their preferred candidate. The fact that lecturers were chosen by election, paid an annual salary decided by the parishioners, and could be dismissed at will inevitably set alarm bells ringing. ${ }^{55}$

Beyond any role that the lecturer might perform, it was still the parish minister's personal style of churchmanship that could have a decisive impact on the performance of Prayer Book worship that parishioners experienced. A zealous puritan preacher might disregard aspects of the official service, as well as seldom wearing the surplice or omitting the sign of the cross in baptism, or turning a blind eye to those who failed to kneel at communion. Equally, he could merely provide a context in which Prayer Book ceremonies were implicitly downgraded by the importance attached to the sermon and to extemporary prayers. By contrast, a more ceremonialist minister might seek to emphasize the sacraments and the more ritualistic aspects of the liturgy, resembling, as Edward Boughen wrote in 1638, an 'Angel of light ... in his white vestment, behaving himselfe with ... gravity, and reverence, and decency', presiding over the whole congregation, 'decently kneeling, rising, standing, bowing, praising, praying altogether ... like men of one mind and religion in the house of God. ${ }^{.56}$ Just as

${ }^{55}$ Merritt, 'Contested Legitimacy', pp. 28, 43; Seaver, Puritan Lectureships, pp. 165-70 and ch. 8 .

${ }^{56}$ Edward Boughen, A Sermon concerning Decencie and Order in the Church (1638), pp. 1011. 
decisive, though, could be the precise balance between the influence and views of the minister, those of the lecturer (if there was one), and the role played by the vestry and other parishioners. We therefore need to be particularly careful to avoid the assumption that the religious experience of parishioners was defined simply by the text of the Prayer Book service. Not only was the message of the service crucially dependent upon the context and style in which it was read, but the actual content of the Prayer Book service could also vary significantly from parish to parish. We know, for example, that services were not standardized, with the minister often juggling parts of the service (such as the position of the sermon, and the inclusion of psalms), while some parishioners came late or attended only part of the service. ${ }^{57}$ There was, then, no generic 'parish Anglican' experience.

It is also problematic to assume that it was the Prayer Book alone that had the greatest influence on the religious sensibility of parishioners. Not only does this reduce our sense of the vital role played by the sermon, but it disregards the importance of other religious exercises conducted in the church and also elsewhere. Not the least of these was metrical psalm singing, in which all the congregation participated, and which was clearly enormously popular in this period. ${ }^{58}$ Outside the services of public worship, public catechizing was one of the minister's critical pastoral duties, which the 1604 canons required to take place every Sunday before evening prayer. Although puritans were sometimes attacked for neglecting catechizing in favour of preaching sermons (a charge that is implicit in the 1629 royal

${ }^{57}$ A. Ryrie, Being Protestant in Reformation Britain (Oxford, 2013), pp. 317-19; P.

Collinson, 'Shepherds, Sheepdogs and Hirelings: the Pastoral Ministry in Post-Reformation England, in his From Cranmer to Sancroft (2006), pp. 50-1, 60, 64-6; Holinshed's Chronicles (6 vols., 1807), I, p. 232; Collinson, Religion of Protestants, pp. 208-9.

${ }^{58}$ A. Ryrie, 'The Psalms and Confrontation in English and Scottish Protestantism', Archiv für Reformationsgeschichte, 101 (2010), pp. 114-37. 
instructions that directed the conversion of afternoon sermons into catechizing), in fact puritan writers were emphatic that preaching without catechizing was fruitless. Indeed, they were the most energetic composers of catechisms, which sold in huge numbers (three quarters of a million of the unofficial catechisms were probably in circulation by the early 1600s). Official catechizing also became more systematic, and was particularly emphasized by Archbishop Bancroft in his metropolitical visitation of ten dioceses in 1605. Problems tended to arise more from parishioners not presenting themselves to be catechized, rather than ministers refusing to catechize them. ${ }^{59}$ Nevertheless, the manner in which the minister chose to conduct his catechizing could provide another important variable in the parochial religious experience.

The high sales of printed catechisms also attest to the popularity of religious instruction in private households as well, and the importance of household worship in complementing (or even undercutting) parochial worship needs to be remembered. Not only were private prayer and household worship important strands in people's religious lives,${ }^{60}$ but parishioners could also organize themselves to participate in other forms of collective religious activity. This had also been true in the medieval Church, where some parishioners had additionally joined fraternities, not all of which were parish-based. Although after the Reformation informal forms of voluntary religious association are most often associated with

${ }^{59}$ G. Bray, ed., The Anglican Canons 1529-1947 (Woodbridge, 1998),p. 349; K. Fincham, ed., Visitation Articles and Injunctions of the Early Stuart Church, 2 vols. (Woodbridge, 1994, 1998), I, p. xxiii; II, p. 38 (cf. pp. 85, 103, 106, 108, 124, 135, 198, 210, 231); I. Green " "For Children in Yeeres and Children in Understanding": The Emergence of the English Catechism under Elizabeth and the Early Stuarts', $\underline{\text { JEH, }} 37$ (1986), p. 425; Ingram, $\underline{\text { Church }}$ Courts, pp. 89-90; Haigh, Plain Man's Pathways, pp. 26-30, 60-63.

${ }^{60}$ Ryrie, Being Protestant, chs. 6-8, 14. 
puritans, they could also be found even among more conservative parishioners, such as the group of 'understanding Soules' -- a Jacobean devotional group that met in Southwark under the auspices of William Austin, a layman whose tastes accorded with those of the Laudians. ${ }^{61}$ More common, though, were the range of supplementary forms of religious exercises in which puritans (lay and clerical alike) shared. While puritans undoubtedly sought to control the institutional framework for local religious practice provided by the parish (as we have seen), at the same time they also devoted time and energy to the fostering of the 'community of the godly'. ${ }^{62}$ Distinctive forms of puritan lay piety emerged that helped to foster this special sense of community and to support those whose mode of living and forms of recreation differed from most in their locality. Examples include the style of household worship famously documented in the daily round of activities recorded by Lady Margaret Hoby in Yorkshire. More generally, puritan sociability included meetings for Bible-reading, sermon repetition (something of a misnomer, since it required reflection and discussion and was designed to evoke a spiritual response), the sharing of stories of individual conversion, and fasting. Ministers were in theory not allowed to appoint or keep fasts either publicly or in private houses without license from the bishop, but fasting nevertheless continued to perform an important role in private and public puritan piety. ${ }^{63}$

${ }^{61}$ G. Parry, Glory, Laud and Honour: the Arts of the Anglican Counter-Reformation (Woodbridge, 2006), pp. 121-3.

${ }^{62}$ P. Collinson, 'Elizabethan and Jacobean Puritanism' in C. Durston and J. Eales, eds., The Culture of English Puritanism 1560-1700 (Basingstoke, 1996), pp. 51-4; Diary of Lady Margaret Hoby, ed. D.M. Meads (1930), pp. 73-5; Hunt, Art of Hearing, pp. 72-7; Ryrie, Being Protestant, p. 359-60; Heal, Reformation, pp. 471-2.

${ }^{63}$ Bray, Canons, p. 363; Collinson, Religion of Protestants, pp. 261-3; Ryrie, Being Protestant, 195-9, 342-4. 
These activities were normally supplementary to parochial religion rather than in direct competition with it (although for some of its participants these may have been more central to their religious experience than was collective parish worship). Sometimes a combination of religious fervour and sense of estrangement from their neighbours might lead 'godly' parishioners to enter into a formal covenant between themselves. Nevertheless, such covenants did not necessarily undermine the parish. Clergy involved in these covenanted groups specifically attacked separation from the Church of England and 'withdrawing from the publick places of Assembly, or from any part of Gods Worship there used'. ${ }^{64}$ At Worksop, about one hundred 'voluntary professors' entered into a covenant 'to watch over one another, to admonish one another...and thereupon to receive the Lord's Supper' under the auspices of their minister, Richard Bernard, but it was said he did so 'in policy' to dissuade them from joining the schismatic Baptist John Smyth. ${ }^{65}$

It should be clear from the foregoing, then, that it is difficult to talk of "parish Anglicans' or 'Prayer Book Protestants': there were too many variables in the religious experience of parish congregations and Prayer Book usage for these to make sense as categories of behaviour or belief. More generally we find a fair degree of eclecticism in the parochial religious experience and its forms of public and private expression. In addition, it is very rare to find a religiously uniform parish. The parish of St Margaret Westminster -- one of the most conservative parishes in the country in its religious style -- had puritan parishioners, but it is notable that they were not involved in parish activities and directed their religious patronage outside the parish. ${ }^{66}$ The Essex village of Terling has provided a famous

\footnotetext{
${ }^{64}$ Samuel Clarke, The Lives of Thirty-Two English Divines (1677), p. 57; Collinson,
} Religion of Protestants, p. 271.

${ }^{65}$ Collinson, Religion of Protestants, pp. 270-1.

${ }^{66}$ Merritt, Social World, p. 323. 
example of a place where social, economic and religious forces of differentiation worked together in the emergence of a puritan oligarchy exerting strict moral control over the local community. But later scholarship has emphasized Terling's unusual and unrepresentative character, and has stressed that the religious configuration of parishes was often more unstable, while social differentiation did not necessarily have a straightforward and predictable impact on the religious life of a parish. ${ }^{67}$ In addition, the enormous geographical diversity of parishes defies any simple categorization of the parochial cultural experience, encompassing as it did differences not only between urban and rural parishes, but also between areas such as fens and uplands, and lowland nucleated settlements. More fundamentally, social factors could affect religious practice in unpredictable ways. The motivations behind the rebuilding or decorating churches, for example, potentially reflected a complex range of incentives on the part of many different actors within a parish, and could include questions of taste and fashion, local identity, and a desire to ensure a venue in which local elites could assert their status. ${ }^{68}$

Models of post-Reformation parish religion must also accommodate the fact that in this period there was significant change over time. Parish communities themselves experienced substantial social and economic change over the sixteenth and early seventeenth centuries. The congregations over which ministers presided also began to alter, with increasing literacy levels and greater exposure to print culture, which held important implications for pastoral endeavours. As we have noted, the potential of the parish to fulfil evangelical and pastoral needs seems to have improved significantly by the Jacobean period as the qualifications and availability of graduate clergy increased, and there was a notable

${ }^{67}$ K. Wrightson and D. Levine, Poverty and Piety in an English Village: Terling, 1525-1700 (New York, 1979), esp. ch. 6; Ingram, Church Courts, pp. 95, 112-13, 116, 166-7. ${ }^{68}$ Spurr, The Post-Reformation, pp. 250-1; Merritt, 'Church-building’, pp. 944-6, 950-55. 
decline in non-residence and pluralism. ${ }^{69}$ At the same time, however, certain forms of parochial ritual activity were undergoing a significant revival. The first decades of the seventeenth century, for example, are notable for the sustained revival of rogationtide processions, and also of the practice of 'festival communions' at Christmas, Whitsun, All Souls, Michaelmas and Midsummer Day. ${ }^{70}$ How far these concurrent trends aided or undermined each other was of course a matter of context. Each parish would experience its own unique (and often precarious) solution to the problem of balancing the needs of the godly and ungodly, and reconciling the evangelical imperative with cohesive communal rituals. But these solutions would come under significant extra pressure from the reign of Charles I onwards.

\section{$\underline{\text { Later Developments }}$}

The interplay of these various elements in parish religion was further complicated by developments in national religious policy from 1625 onwards. The first of these was the impact of the policies of Archbishop Laud and his supporters. Laudianism had its most direct impact in the interiors of parish churches, where the communion table was required to be removed to the east end of the church and railed in, alongside an intensified programme of the beautification of church interiors, summarized in the term 'the beauty of holiness' ${ }^{71}$ As

\footnotetext{
${ }^{69}$ Ingram, Church Courts, pp. 86-9; Collinson, Religion of Protestants, ch. 3.

${ }^{70}$ Hutton, Rise and Fall, pp. 175-7.

${ }^{71}$ P. Lake, 'The Laudian Style: Order, Uniformity and the Pursuit of the Beauty of Holiness in the 1630s' in K. Fincham, ed., The Early Stuart Church (Basingstoke, 1993), pp. 161-85;
} A. Foster, 'Church Policies of the 1630s' in R. Cust and A. Hughes, eds., Conflict in Early Stuart England (Harlow, 1989), pp. 203-6; K. Fincham and N. Tyacke, Altars Restored (Oxford, 2007), chs. 5-6. 
we have already noted, for some communities, decorating and preserving the local church may have appealed to a sense of 'seemliness' and parochial pride, and need not have been inherently objectionable, without there being a need to categorize such parishioners as 'lay Laudians' (a misleading umbrella term -- especially before the 1630s -- that imposes a false coherence on a complex range of lay motives for church beautification and ceremonialism). ${ }^{72}$ By the end of the 1630s the country seems to have displayed fairly high levels of compliance with the policy of railed east-end altars, although some of this must have been reluctant. ${ }^{73}$ Other aspects of the Laudian reforms may have prompted greater opposition. More elaborate forms of worship (including the observance of ceremonies that may have been seen as popish, such as bowing at the name of Jesus), and the enhancing of the status of the minister, could generate unease on a number of levels. More generally, it was the Laudian drive for ceremonial and architectural uniformity (including the cutting down of pews to a uniform size) that potentially rode roughshod over the many idiosyncrasies of local worship and religious expression, and doubtless alienated broader bodies of opinion. ${ }^{74}$ The authorities' more intensive regulation of clerical behaviour -- imposing ceremonial conformity, disciplining puritan ministers, and suspending lectureships -- not only interfered with local

${ }^{72}$ Merritt, 'Church-building', pp. 942-46, 953-56; M. Reynolds, Godly Reformers and their Opponents, (Woodbridge, 2005), pp. 14-15, ch. 9; Fincham and Tyacke, Altars Restored, pp. $253-73$.

${ }^{73}$ Fincham and Tyacke, Altars Restored, pp. 172-210.

${ }^{74}$ A. Walsham, 'The Parochial Roots of Laudianism Revisited: Catholics, Anti-Calvinists and “Parish Anglicans" in Early Stuart England', JEH, 49 (1998), pp. 622-3; D. Cressy, 'Conflict, Consensus and the Willingness to Wink: the Erosion of Community in Charles I's England', Huntington Library Quarterly 61 (1998), pp. 144-6, 149; Foster, 'Church Policies', pp. 20010, 215-16; P. Marshall, Reformation England 1480-1642 (2012 edn.), pp. 227-8. 
religious activities, but was part of the ecclesiastical authorities' increasing desire to restrict the exercise of power by laypeople over the clergy. Overall, Laudianism threatened many of the ways in which local people had customized aspects of worship and religious life in each parish, as well as potentially altering relations between ministers and parishioners. ${ }^{75}$

The downfall of Laudianism in 1640 ushered in a period of dramatic change in local and national religion and politics. The national Church was dismantled, with the abolition of bishops, deans and chapters, and church courts, but their replacement was less clear. On the local parish level there was the ejection of over 2,000 clergymen, while church buildings themselves were subject to bouts of iconoclasm, stone fonts were abandoned, and parish churches lost the word 'Saint' from their titles. Prayer Book services were also replaced by more extemporary services, following the broad-brush outlines and suggestions of the Directory for Public Worship. ${ }^{76}$

But amid all this change, parish structures proved remarkably resilient. Even when there were attempts in the 1640 s to establish a Presbyterian church government, the features of the traditional parish -- especially urban ones -- could actually support Presbyterianism very easily. Vestries had been accused in the 1620 s of introducing Presbyterianism by stealth, and could naturally assume the function of presbyteries. Similarly, it was observed in Westminster Assembly debates that elders could grow naturally out of the roles performed by

${ }^{75}$ J.T. Cliffe, The Puritan Gentry (1984), pp. 158-64, 169-71; Merritt, Social World, pp. 3448.

${ }^{76}$ J. Spraggon, Puritan Iconoclasm during the English Civil War (Woodbrigde, 2003), chs. 45; F. McCall, Baal's Priests. The Loyalist Clergy and the English Revolution (Farnham, 2013). 
churchwardens. ${ }^{77}$ The hierarchy of synods that was initially intended rarely assembled outside London and Lancashire, and as a result parishes continued to be run much as before, albeit now without episcopal overview. Vestries were in effect as active as ever. And by the 1650 s it is possible to observe a gradual pattern of the revival of earlier forms of collective ritual activity in parishes, and even the name 'Saint' started to return to parish documents. ${ }^{78}$

The decisive change for local communities was the explosion of nonconformity and different sects. The ideal of local religious unity was in some senses abandoned, and attendance at a single local parish church was no longer required (in contrast to the pre-1640 period, when members of sects such as the Family of Love continued to play important roles within their local parish). ${ }^{79}$ But there was still a national church settlement of sorts, and it has been observed that 'all research suggests that most English people attended parochial worship rather than a gathered congregation or a sect'. The parish remained a key administrative unit, and the parish church remained a principal focus of the local community, continuing to act as the local school, storehouse and arsenal, and as the venue for many types of local meetings and announcements (and sometimes court sessions). ${ }^{80}$

\footnotetext{
${ }^{77}$ A. Milton, Laudian and Royalist Polemic in Seventeenth-century England (Manchester, 2007), p. 96.

${ }^{78}$ J.F. Merritt, Westminster 1640-60: A Royal City in a Time of Revolution (Manchester, 2013), pp. 248-54.
}

${ }^{79}$ C.W. Marsh, The Family of Love in English Society, 1550-1630 (Cambridge, 1994), pp. $96,170-73,182-97$.

${ }^{80}$ A. Hughes, “ "The Public Profession of These Nations”: the National Church in Interregnum England' in C. Durston and J. Maltby, eds., Religion in Revolutionary England (Manchester, 2006), p. 96. 
The abolition of Christmas and the implementation of a stringent Sabbatarian discipline were perhaps some of the most immediately visible changes that parishioners encountered. ${ }^{81}$ But there were also more creative developments: in some places, ministers sought to revivify the parish's pastoral engagement by means of ambitious programmes of lecture exercises. However, initially the puritan urge to separate godly and ungodly seems to have been given free rein within the parish community, with a greater stress on exclusion from communion, but the tension this created with the parish's social role soon became apparent. Occasionally inhabitants refused to pay the poor rate if they were excluded from communion. The pragmatic solution adopted by some clergy was to not celebrate communion at all, rather than initiating socially divisive distinctions on the calculation of relative sincerity of belief. ${ }^{82}$ Instead, they retained some of the more inclusive parochial rituals, such as perambulation (although the opponents of Presbyterians jeered that they did so simply to ensure that the boundaries caught as many people as possible in the net of tithe-payers). The Congregationalist Giles Firmin thought it absurd that Presbyterian ministers could exclude half the parish at communion, yet also felt bound to baptize all the children. In Ralph Josselin's parish, people claimed that paying tithes and rates entitled them to a place in church, even if they were not especially 'godly' or in sympathy with the minister. ${ }^{83}$ However, not only did Presbyterian ministers continue to fulfil normal parochial duties, but most

${ }^{81}$ B. Capp, Culture Wars (Oxford, 2012), esp. pp. 20-24, 100-110.

${ }^{82}$ Merritt, Westminster 1640-60, pp. 234-7, 240-43; E. Vernon, 'A Ministry of the Gospel: the Presbyterians during the English Revolution' in Durston and Maltby, Religion in Revolutionary England, pp. 115-36.

${ }^{83}$ S. Hardman Moore, Pilgrims: New World Settlers and the Call of Home (New Haven, Connecticut, 2007), p. 137; Abraham Boun, The Pride and Avarice of the Clergie (1650), pp. 51, 168-72; Collinson, 'The English Conventicle' in Collinson, From Cranmer, pp. 170-71. 
Congregational churches in the 1650s existed in a parochial format, with Congregationalist ministers holding a parish living and operating what was essentially a two-tier pastorate. That is, access to the sacraments was restricted to covenanted 'saints' (who alone constituted the true 'church') but fellowship, prayer, preaching and psalm-singing were open to all the parish, and Congregationalist ministers were committed to preaching the gospel and promoting reformation within the parish system. ${ }^{84}$

By contrast, upholders of earlier Prayer Book worship may sometimes have been willing to abandon parochial structures, especially when their own parish was taken over by a puritan minister. The image of the persecuted Anglican John Evelyn attending clandestine Prayer Book services is a familiar one. Similarly, when in the 1650s Sir John Bramston went to seek out a church service in the capital for his elderly father 'where the orthodox clergie preacht and administered the sacraments', he managed to stumble across one in Milk Street (he also describes better-known venues which had the disadvantage of 'the soldiers often disturbing those congregations'). ${ }^{85}$ But while these accounts show that such services might be available, including in private houses, they also demonstrate that devotees of the Prayer Book often worshipped outside parish structures. Ironically, the existence of royalist 'congregations' in London and elsewhere suggests that such episcopalians were implicitly

${ }^{84}$ J. Halcomb, 'A Social History of Congregational Religious Practice during the Puritan Revolution', PhD thesis (University of Cambridge, 2009), pp. 101-15; Hardman Moore, $\underline{\text { Pilgrims, pp. 132-7, 140; J. Coffey, 'Church and State, 1550- 1750' in R. Pope, ed., T \& T }}$ Clark Companion to Nonconformity (2013), p. 59.

${ }^{85}$ The Autobiography of Sir John Bramston K.B., ed. P. Braybrooke (Camden Society, 32, 1845), pp. 91-2; Diary and Correspondence of John Evelyn, ed. W. Bray, 4 vols. (1850), I, pp. 323, 326, 333, 334 . 
undermining the idea of a common 'parish' community (even if they would have preferred to return to parish-based worship).

At the Restoration, though, the settlement saw parish religion more rigorously based around acceptance of the Prayer Book, the exclusion of nonconforming clergy (with some 1,760 English clergy forced to leave their parishes between 1660 and 1663), ${ }^{86}$ and the later formalization of Dissent. The idea that the local religious and social community were coextensive was effectively abandoned. Nevertheless, the 1660s witnessed a series of awkward compromises, with moderate puritans still attending their local church, while the ideal of a parish whose religious inclusivity would match its all-encompassing civil jurisdiction was still remarkably tenacious. Even Presbyterian clergy taking out licences to be permitted free public worship under the 1672 Declaration of Indulgence claimed that this was not about embracing schism, and that they were assisting parish ministers and extending the scope of the local ministry. By licensing dissenting ministers, it was suggested, the king was incorporating them into the church national: these were quasi-parishes. ${ }^{87}$

\section{$\underline{\text { Conclusion }}$}

As should be clear, 'parish religion' was in this period the outcome of the shifting combination of a whole range of different social, religious and political forces, whose precise configuration was unique to each individual parish. The challenge of making the parish work as both a social and a religious institution exposed different assumptions about what constituted true 'order' and what the scope of the religious community truly was. This was a

\footnotetext{
${ }^{86}$ Spurr, Post-Reformation, p. 147.

${ }^{87}$ M. Goldie, 'Toleration and the Godly Prince in Restoration England' in Morrow and Scott, eds., Liberty, Authority, Formality (Exeter, 2008), p. 64.
} 
world in which many polarities loomed: between the godly and ungodly, laity and clergy, public and private religion, collective and exclusive views of religious fellowship, cohesive and divisive visions of the minister's message, communal and oligarchic forms of local governance. The parochial experience was shaped by the ways in which these potential divisions were negotiated, by the minister, by the vestry and ultimately by the individual parishioner. The English parish in this period was the arena in which these variously balanced forces operated, and where implicit or explicit compromises were devised, negotiated or rejected. It was not the receptacle of a simple 'parish Anglicanism'. Rather, what emerges from a study of the parish in the century or more following the Henrician Reformation is the extraordinary tenacity with which the parish continued, despite all the revolutionary changes, to be central to the social identity and experience of early modern English men and women. But the precise religious implications of that social experience would vary significantly, and cannot be subsumed within an ideology of 'Anglicanism', no matter how capaciously defined.

\section{$\underline{\text { Select Bibliography }}$}

J.P. Boulton, 'The Limits of Formal Religion: the Administration of Holy Communion in Late Elizabethan and Early Stuart London', London Journal 10 (1984), pp. 135-54

P. Collinson, The Religion of Protestants (Oxford, 1982)

J. Craig, 'Psalms, Groans and Dog-Whippers: The Soundscape of Sacred Space in the English Parish Church, 1547-1642', in W. Coster and A. Spicer (eds.), Sacred Space in Early Modern Europe (Cambridge, 2005), pp. 104-23 
K. French, G. Gibbs, and B. Kümin, eds., The Parish in England Life 1400-1600

(Manchester, 1997)

C. Hill, Economic Problems of the Church, (Oxford, 1956)

Steve Hindle, 'Beating the Bounds of the Parish: Order, Memory and Identity in the English Local Community, c. 1500-1700', in M. Halvorson and K. Spierling, eds., Defining

Community in Early Modern Europe (Aldershot, 2008), pp. 205-28

A. Hunt, 'The Lord's Supper in Early Modern England', Past \& Present, 161 (1998), pp. 39-

83

M. Ingram, Church Courts, Sex and Marriage in England, 1570-1640 (Cambridge, 1987)

B. Kümin, The Shaping of a Community: The Rise and Reformation of the English Parish c. $\underline{1400-1560}$ (Aldershot, 1996)

J. Maltby, Prayer Book and People in Elizabethan and Early Stuart England (Cambridge, 1998)

C.W. Marsh, “"Common Prayer” in England 1560-1640: the View from the Pew', Past \& Present 171 (2001), pp. 66-94

J.F. Merritt, 'Contested Legitimacy and the Ambiguous Rise of Vestries in Early Modern London', Historical Journal, 54 (2011), pp. 25-45

J.F. Merritt, 'Puritans, Laudians, and the Phenomenon of Church-building in Jacobean London', Historical Journal, 41 (1998), pp. 935-60

J.F. Merritt, The Social World of Early Modern Westminster: Abbey, Court and Community $\underline{1525-1640}$ (Manchester, 2005)

A. Walsham, Charitable Hatred: Tolerance and Intolerance in England 1500-1700

(Manchester, 2006)

S. Wright, ed., Parish, Church and People (1988) 
K. Wrightson, 'The Politics of the Parish in Early Modern England' in P. Griffiths, A. Fox, and S. Hindle, eds., The Experience of Authority in Early Modern England (Basingstoke, 1996) 